\title{
PENGARUH PERTUMBUHAN EKUITAS DAN PERTUMBUHAN LABA TERHADAP INVESTMENT OPPORTUNITY SET
}

(Studi Empiris pada Industri Properti dan Real Estate di BEI Periode Tahun 20042008).

Oleh

Karsam

(Dosen Program Studi Akuntansi Universitas Pendidikan Indonesia)

\section{Yanalia Salampessy}

\begin{abstract}
Abstrak
Penelitian ini menggunakan sampel 35 perusahaan yang bergerak di dalam Industri properti dan Real Estate yang terdaftar di Bursa Efek Indonesia (BEI) periode tahun 2004-2008. Sumber data adalah data sekunder yang diperoleh dari Indonesian Capital Market Directory dengan pengumpulan data dilakukan dengan cara time series. Hasil analisis yang dilakukan menunjukkan bahwa secara simultan Pertumbuhan Ekuitas dan Pertumbuhan Laba mempengaruhi Investment Opportunity Set khususnya pada rasio Market Book Value of Asset (MBVA). Sedangkan secara parsial, Pertumbuhan Ekuitas dan Pertumbuhan Laba berpengaruh secara signifikan terhadap Investment Opportunity Set khususnya pada rasio Market Book Value of Asset (MBVA).
\end{abstract}

Kata-kata kunci: Investment Opportunity Set, Market Book Value of Asset $(M B V A)$, Pertumbuhan Ekuitas, Pertumbuhan Laba.

\section{Pendahuluan}

Pertumbuhan perusahaan merupakan harapan dari berbagai pihak baik pihak internal perusahaan maupun eksternal perusahaan. Pertumbuhan perusahaan diharapkan dapat memberikan sinyal positif adanya kesempatan berinvestasi. Bagi investor, prospek perusahaan yang memiliki potensi tumbuh tinggi memberikan keuntungan karena investasi yang ditanamkan diharapkan akan memperoleh tingkat pengembalian yang tinggi di masa yang akan datang. Peluang pertumbuhan perusahaan dapat diproksikan dengan berbagai macam kombinasi kesempatan investasi atau disebut sebagai Investment Opportunity Set (IOS) (Hossain et all., 2000).

Sampai dengan akhir 2008 beberapa peristiwa telah menjadi hambatan yang mempengaruhi kinerja dari sektor properti. Meroketnya harga minyak dunia sampai dengan diatas 100 US Dollar per barrel dari awal sampai dengan peitengahan tahun 2008 mengakibatkan naiknya biaya pembangunan maupun perawatan dari suatu bangunan.

Tingginya suku bunga pada tahun 2008 juga ikut menyumbang masalah terhadap sektor properti. Selama tahun 2008 suku bunga Bank Indonesia telah beberapa kali mengalami peningkatan untuk memerangi inflasi, walaupun diakhir tahun sempat terjadi penurunan 25 basis poin. Dengan terus naiknya suku bunga Bank Indonesia akan merangsang terjadinya suku bunga pinjaman yang tinggi. 
Selama tahun 2008 tingkat suku bunga Kredit Pemilikan Rumah (KPR) sudah mengalami peningkatan yang cukup besar dari awal tahun 2008.

Di dalam lampiran 11 Surat Edaran Ketua Badan Pengawas Pasar Modal Nomor : SE-02 /PM/2002 Tanggal : 27 Desember 2002, siklus operasi normal perusahaan pengembang pada umumnya lebih dari satu tahun dan dipengaruhi oleh faktor ketidakpastian yang cukup tinggi. Banyak risiko yang mungkin timbul dalam aktivitas subsektor industri Real Estate, di antaranya adalah : (1) Risiko Keberadaan Tanah; (2) Risiko Gugatan hukum; (3) Peraturan Pihak Terkait; (4) Risiko berfluktuasinya nilai tukar rupiah; (5) Risiko Pemogokan atau kerusuhan (riot); (6) Risiko tidak tertagihnya piutang (accounts receivable risk); (7) Risiko Bencana Alam.

Penelitian ini dilakukan untuk mengetahui sejauh mana pengaruh Pertumbuhan Ekuitas dan Pertumbuhan Laba terhadap Investment Opportunity Set dengan mempergunakan rasio Market Book Value to Asset (MBVA).

Walaupun krisis keuangan global mendera, tetap saja perusahaan berusaha agar nilai perusahaannya meningkat. Untuk meningkatkan nilai perusahaan maka perusahaan dituntut untuk tumbuh agar dapat memaksimumkan kekayaan para investor. Pertumbuhan tersebut dapat diwujudkan apabila perusahaan menggunakan peluang investasi sebaik-baiknya.

Pertumbuhan perusahaan tetap merupakan harapan yang diinginkan oleh semua pihak, baik pihak internal perusahaan (manajemen) dan pihak eksternal perusahaan (investor dan kreditor). Pertumbuhan ini diharapkan dapat memberikan aspek yang positif bagi perusahaan seperti adanya suatu kesempatan berinvestasi di perusahaan tersebut.

Bagi investor, pertumbuhan perusahaan dapat menjadi salah satu pertimbangan untuk memperkirakan prospek suatu perusahaan dalam menghasilkan laba di masa yang akan datang.

Pada perusahaan dengan tingkat kesempatan investasi yang besar, tingkat asimetri informasi akan cenderung relatif tinggi. Kadangkala manajer memiliki informasi privat tentang nilai proyek di masa mendatang dan tindakan mereka seringkali tidak dapat diawasi dengan detail oleh para pemegang saham.

Bentuk yang membedakan pilihan investasi adalah nilai perusahaan itu tergantung pada kebebasan pemilihan pengeluaran yang ditentukan oleh manajer di masa depan. Semakin banyak proksi IOS yang menentukan kelompok atau karakteristik perusahaan, semakin mengurangi kesalahan dalam penentuan klasifikasi tingkat pertumbuhan perusahaan.

Dalam banyak penelitian tentang Investment Opportunity Set, proksi yang sering digunakan antara lain : (1) Rasio Market to Book Value of Equity (MVEBVE) dengan dasar pemikiran bahwa pasar menilai return dari investasi perusahaan di masa yang akan datang lebih besar dari return yang diharapkan dari ekuitasnya; (2) Rasio Price to Earning Ratio (PER) dengan dasar pemikiran bahwa semakin besar rasio PER maka semakin besar pula investasi aktiva produktifnya; (3) Rasio Capital Expenditure to Book Value of Asset (CAPBVA) menunjukkan adanya aliran tambahan modal saham perusahaan yang dapat digunakan untuk tambahan investasi aktiva produktifnya; (4) Rasio Capital Expenditure to Market Value of Asset (CAPMVA) dengan dasar pemikiran bahwa 
perusahaan yang tumbuh memiliki level aktivitas investasi yang lebih tinggi dibanding dengan perusahaan yang tidak tumbuh; (5) Rasio Firm Value to Book Value of Property, Plant and Equiptment (VPPE) menunjukkan adanya investasi pada aktiva tetap yang produktif sebagai asset in place; (6) Rasio Current Assets to Net Sales (CAONS) dengan dasar pemikiran bahwa working capital dapat digunakan untuk investasi perusahaan yang berasal dari asset perusahaan. Dengan investasi pada current assets akan mampu menghasilkan penjualan sebesar net sales yang diterima.

Berdasarkan identifikasi masalah yang ada, dalam hal Investment Opportunity Set (IOS) maka penulis memakai satu rasio saja yaitu Market Book Value to Asset (MBVA) serta membatasi pada variabel yang dapat mempengaruhi rasio Market Book Value to Asset (MBVA), yaitu : (1) Variabel Pertumbuhan Ekuitas (X1); (2) Variabel Pertumbuhan Laba (X2).

Ruang lingkup ini adalah: (1) Penelitian ini dilakukan di Bursa Efek Indonesia, dengan subyek penelitian adalah laporan keuangan perusahaan perusahaan sektor properti dan real estate yang terdaftar di BEI dari tahun 20042008 yang dianggap lengkap; (2) Variabel yang diteliti adalah yang berkaitan dan dalam penelitian ini penulis membatasi pada pengaruh Pertumbuhan Ekuitas, Pertumbuhan Hutang dan Pertumbuhan Laba terhadap Investment Opportunity Set (IOS) dengan memakai rasio Market Book Value to Asset (MBVA).

Berdasarkan batasan masalah diatas, dapat ditarik rumusan masalah sebagai berikut: (1) Apakah Pertumbuhan Ekuitas dan Pertumbuhan Laba berpengaruh secara simultan terhadap Investment Opportunity Set (IOS)?; (2) Apakah Pertumbuhan Ekuitas dan Pertumbuhan Laba berpengaruh secara parsial terhadap Investment Opportunity Set (IOS)?.

Sesuai dengan rumusan masalah, penelitian ini mempunyai tujuan sebagai berikut: (1) Mengetahui seberapa besar pengaruh Pertumbuhan Ekuitas dan Pertumbuhan Laba berpengaruh secara simultan terhadap Investment Opportunity Set (IOS); (2) Mengetahui seberapa besar pengaruh Pertumbuhan Ekuitas dan Pertumbuhan Laba berpengaruh secara parsial terhadap Investment Opportunity Set (IOS).

Hasil dari penelitian ini diharapkan mempunyai manfaat dan kegunaan sebagai berikut : (1) Bagi para emiten, hasil penelitian ini dapat menjadi masukan dan bahan pertimbangan dalam pengambilan keputusan; (2) Bagi akademisi, penelitian ini akan memberikan arah studi tentang Investment Opportunity Set (IOS) umumnya dan rasio Market Book Value to Asset (MBVA) khususnya; (3) Bagi praktisi, hasil penelitian akan memberikan gambaran tentang faktor-faktor yang mempengaruhi Investment Opportunity Set (IOS) dengan mempergunakan rasio Market Book Value to Asset (MBVA); (4) Bagi peneliti selanjutnya, hasil penelitian dapat dimanfaatkan sebagai bahan referensi untuk penelitian lebih lanjut.

\section{Kajian Pustaka}

Investment Opportunity Set (IOS) menurut Myers (1977) yang dikutip dari (Gumanti dan Puspitasari, 2008) adalah kombinasi antara aktiva yang dimiliki perusahaan (assets in place) dan pemilihan investasi pada masa yang akan datang 
dengan net present value (NPV) positif. Sementara Gaver dan Gaver (1993), Investment Opportunity Set (IOS) adalah nilai perusahaan yang besarnya tergantung pada pengeluaran yang akan datang uang ditetapkan oleh manajemen, yang pada saat ini sebagai alternatif investasi yang expected returnnya lebih besar. Perbedaan nilai buku saham dan nilai pasar tidak lain adalah Investment Opportunity Set ( IOS ) yang merupakan potensi pertumbuhan untuk masa yang akan datang. Kenaikan nilai perusahaan yang dihasilkan dari berbagai alternatif pilihan kesempatan investasi perusahaan dimasa yang akan datang adalah Investment Opportunity Set (IOS) (Myers, (1977); Smith, dan Watts (1992) yang dikutip dari (Gumanti dan Puspitasari, 2008).

Terdapat perbedaan makna antara pertumbuhan dan Investment Opportunity Set (IOS). Investment Opportunity Set (IOS) adalah pilihan investasi yang menghasilkan Net Profit Value (NPV) positif, sedangkan pertumbuhan adalah kemampuan perusahaan untuk meningkatkan ukuran (McDonald dan Siegel, 1986; dan Pindick, 1988) yang dikutip dari (Gumanti dan Puspitasari, 2008). Menurut Jensen (1986) yang dikutip dari (Gumanti dan Puspitasari, 2008), bahwa investasi dari kas untuk akuisisi meningkatkan ukuran perusahaan tanpa nilai. Kemampuan perusahaan untuk mengakuisisi perusahaan lain bukan komponen Investment Opportunity Set (IOS) dan tidak menghasilkan nilai.

Beberapa proksi Investment Opportunity Set (IOS) telah digunakan dalam bidang akuntansi dan keuangan untuk memahami pemikiran Investment Opportunity Set (IOS) (Myers dalam Subekti dan Kusuma. 2000). Kallapur dan Trombley, yang dikutip Prasetyo, 2000, menyatakan bahwa proksi-proksi tersebut dapat digolongkan menjadi tiga jenis yaitu: (1) Proksi Investment Opportunity Set (IOS) berbasis pada harga.Investment Opportunity Set (IOS) yang didasari pada harga akan berbentuk suatu rasio sebagai suatu ukuran aktiva yang dimiliki dan nilai pasar perusahaan; (2) Proksi Investment Opportunity Set (IOS) berbasis pada investasi, merupakan proksi yang percaya pada gagasan bahwa suatu level kegiatan investasi yang tinggi berkaitan secara positif dengan nilai Investment Opportunity Set (IOS) suatu perusahaan; (3) Proksi Investment Opportunity Set (IOS) berbasis pada varian (variance measurement).

Rasio Market to Book Value of Asset (MBVA) diharapkan dapat mencerminkan peluang investasi yang dimiliki perusahaan. Hal ini dapat dijelaskan melalui hubungan bahwa semakin rendah Market to Book Value of Asset maka akan semakin tinggi nilai Investment Opportunity Set (IOS) perusahaan. Gaver \& Gaver (1993) yang dikutip dari (Agustina M.V, Norpratiwi, 2001) juga menemukan bahwa semakin tinggi rasio nilai pasar aktiva terhadap nilai buku, maka akan semakin tinggi pula nilai Investment Opportunity Set (IOS). Hal yang sama juga ditemukan oleh Sami et al. (1999) dan Hartono (1999). Kallapur dan Trombley (1999) yang dikutip dari (Agustina M.V, Norpratiwi, 2001) menyatakan pula bahwa rasio nilai buku aktiva terhadap nilai pasar mengarah pada investasi realisasi.

Menurut Kallapur dan Trombley (2001) yang dikutip dari (Gumanti dan Puspitasari, 2008), pertumbuhan merupakan kemampuan perusahaan untuk meningkatkan size perusahaan, sedangkan tidak semua growth opportunities memiliki Net Profit Value (NPV) yang positif. 
Penelitian Vogt (1997) yang dikutip dari (J.C.Shanti dan C.Bintang Hari Yudhanti, 2005) menunjukkan bahwa perusahaan yang bertumbuh akan direspon positif oleh pasar. Menurut Smith dan Watts (1992), peluang pertumbuhan perusahaan tersebut terlihat pada kesempatan investasi yang diproksikan dengan berbagai macam kombinasi nilai set kesempatan investasi (investment opportunity set $=$ IOS).

Ekuitas adalah modal yang berasal dari pemilik perusahaan untuk jangka waktu yang tidak tentu lamanya. Menurut Riyanto (1990; 225), Ekuitas adalah modal yang berasal dari pemilik perusahaan dan yang tertanam dalam perusahaan dalam jangka waktu tertentu lamanya.

Menurut Suwardjono (2006:514), definisi tersebut tidak berbeda dengan yang dikemukakan oleh FASB dalam SFAC No. 6, yaitu: "Equity or net asset is the residual interest in the asset of an entity that remains after deducting its liabilities". Ini berarti ekuitas bukan pengorbanan sumber ekonomik masa datang. Karena didefinisi atas dasar asset dan kewajiban, nilai ekuitas juga bergantung pada bagaimana aset dan kewajiban diukur.

Pertumbuhan ekuitas dalam penelitian ini dilakukan dengan membandingkan ekuitas dari satu periode ke periode berikutnya.

Laba secara operasional merupakan perbedaan antara pendapatan yang direalisasi yang timbul dari transaksi selama satu periode dengan biaya yang berkaitan dengan pendapatan tersebut. Sedangkan pengertian laba menurut IAI dalam Chariri dan Ghozali (2003:213) adalah kenaikan manfaat ekonomi selama satu periode akuntansi dalam bentuk pemasukan atau penambahan aktiva atau penurunan kewajiban yang mengakibatkan kenaikan ekuitas yang tidak berasal dari kontribusi peranan modal. Besar kecilnya laba sebagai pengukur kenaikan sangat bergantung pada ketepatan pengukuran pendapatan dan biaya. Jadi dalam hal ini laba hanya merupakan angka artikulasi dan tidak didefinisikan tersendiri secara ekonomik seperti halnya aktiva atau hutang (Chariri dan Gozali, 2003:213).

Menurut Hanafi dan Halim sebagaimana dikutip Angkoso (2006) menyebutkan bahwa pertumbuhan laba dipengaruhi oleh beberapa faktor antara lain: (1) Besarnya perusahaan; (2) Umur perusahaan; (3) Tingkat leverage; (4) Tingkat penjualan; (5) Perubahan laba masa lalu.

Myers (1977) yang dikutip dari (Gumanti dan Puspitasari, 2008) menyatakan bahwa nilai perusahaan sebagai kombinasi antara aset yang dimiliki dan peluang investasi. Laba yang tinggi memberikan sinyal mengenai pertumbuhan perusahaan di masa yang akan datang. Disebutkan juga oleh AlNajar dan Belkauoi (1999) yang dikutip dari (Gumanti dan Puspitasari, 2008) bahwa sebagian dari laba tersebut akan ditanamkan lagi dalam bentuk investasi untuk meningkatkan perusahaan.

Hasil-hasil penelitian sebelumnya yaitu Smith dan Watts (1992) menggunakan data perusahaan pada level industri. Proksi utama Investment Opportunity Set (IOS) yang digunakan adalah book value of assets to firm value. Proksi kebijakan pendanaan yang digunakan adalah equity to value yang diukur dengan equity/market value of firm. Ada juga penelitian Gaver dan Gaver (1993) dikutip dari (Iswahyuni dan Suryanto, 2002) Analisis common factor digunakan dalam membentuk indeks IOS perusahaan dengan menggunakan 6 proksi, yaitu: 
(1) market value of firm to book value of assets ratio, (2) market to book value of equity ratio, (3) earnings/price ratio, (4) RdanD expenditures to book value of assets ratio, (5) the variance of the total return of the firm, dan (6) the frequency that firm is included in the holdings of growth-oriented mutual fund. Hasil ini sesuai dengan hipotesis kontrak bahwa perusahaan bertumbuh cenderung memiliki leverage yang lebih rendah dibanding perusahaan tidak bertumbuh.

Selanjutnya Gaver dan Gaver (1995) telah melakukan penelitian dengan judul "Compensation Policy and the Investment Opportunity Set." Ada empat proksi yang digunakan, yaitu: MKTBKASS, MKTBEQ, VAR dan R\&D. Dan Kallapur dan Trombley (1999) telah melakukan penelitian dengan judul "The Association between Investment Opportunity Set Proxies and Realized Growth" Karakteristik penelitian ini adalah memperluas pembahasan realisasi pertumbuhan. Karakteristik ini di Indonesia direplikasi oleh Tettet Fitrijanti dan Jogiyanto Hartono.

Myers (1984), Myers dan Majluf (1984), menyatakan bahwa perusahaan mempunyai kecenderungan untuk menentukan pemilihan sumber pendanaan yaitu dengan internal equity dahulu, Apabila investasi perusahaan tersebut sebagian besar didanai dari internal equity, maka hal tersebut akan mempengaruhi besarnya dividen yang akan dibagikan kepada pemegang saham. Jika ekuitas meningkat, maka Investment Opportunity Set akan meningkat pula.

Perusahaan yang tumbuh cenderung labanya meningkat, sehingga pasar juga memberikan respon yang positif. Oleh karena itu, jika pertumbuhan laba terja di maka Investment Opportunity Set akan meningkat pula.

Semua variabel diatas, secara tidak langsung berpengaruh terhadap Investment Opportunity Set (IOS) pada perusahaan Properti dan real estate.

Berdasarkan kerangka pemikiran teoritis yang dibangun oleh peneliti terdahulu, maka dapat diilustrasikan berikut ini :

Gambar 2.5 Skema Kerangka Pemikiran Teoritis

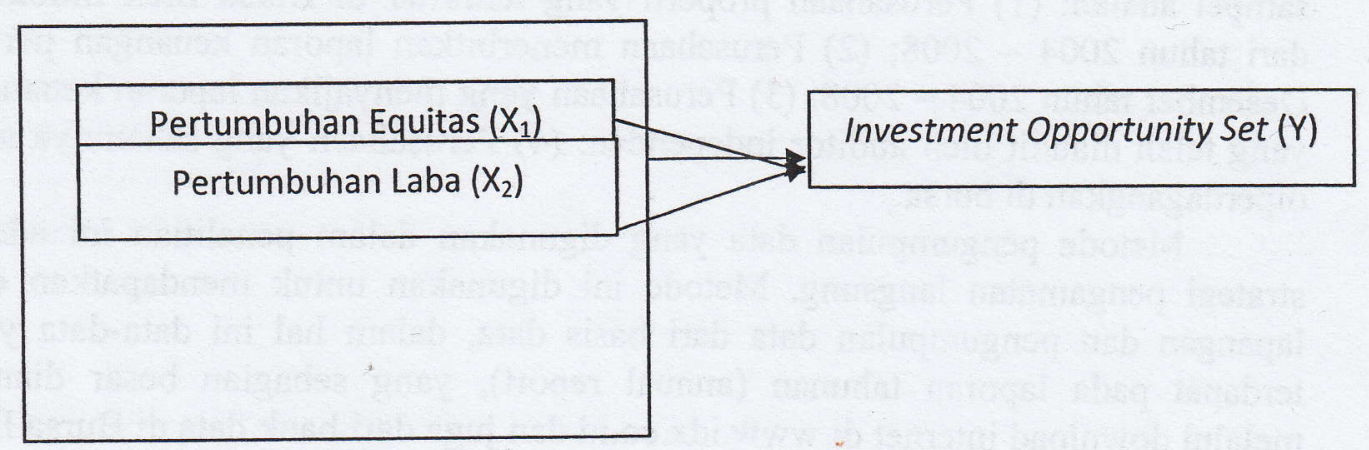

Mengacu pada kerangka pemikiran diatas, maka rumusan alternatif dari penelitian ini adalah:

Hal : Pertumbuhan ekuitas secara signifikan berpengaruh secara parsial terhadap Investment Opportunity Set.

$\mathrm{Ha} 2$ : Pertumbuhan laba secara signifikan berpengaruh secara parsial terhadap Investment Opportunity Set. 
Ha3 : Pertumbuhan ekuitas dan pertumbuhan laba secara simultan berpengaruh terhadap Investment Opportunity Set.

\section{Metode Penelitian}

Penelitian dilakukan di Bursa Efek Indonesia yang beralamat di Jakarta Stock Exchange Building, Jalan Jendral Sudirman Kav. 52-53, Jakarta 12190. Penelitian ini dilakukan selama 5 bulan, yaitu dari bulan Desember 2009 sampai dengan April 2010.

Data Sekunder adalah data yang diperoleh bukan langsung dari sumbernya dan bukan usaha sendiri oleh peneliti (Sudjana, 1981: 52) Data ini sudah tersedia sebelumnya sehingga peneliti tidak perlu mengusahakan sendiri pengumpulanya, dari data sekunder juga juga dipakai literatur-literatur di perpustakaan yang ada hubunganya dengan yang masalah-masalah yang diteliti.

Menurut Uma Sekaran (2006:65), data sekunder mengacu pada informasi yang dikumpulkan oleh seseorang, dan bukan peneliti yang melakukan studi mutakhir.

Dalam penelitian ini jenis data yang digunakan adalah data sekunder, yang diperoleh dari laporan tahunan (annual report) dari perusahaan properti dan data yang digunakan merupakan gabungan data antar perusahaan properti (cross section) dan data antar waktu (time series), yang disebut juga dengan pooling data.

Populasi penelitian ini adalah seluruh perusahaan properti yang terdaftar di Bursa Efek Indonesia periode 2004-2008 dan telah mempublikasikan laporan keuangan berturut-turut selama periode pengamatan sampel. Agar dapat memenuhi jumlah sampel, maka peneliti menggunakan metode pooling data (time series).

Penentuan kriteria sampel diperlukan untuk menghindari timbulnya kesalahan dalam penentuan sampel penelitian, yang selanjutnya akan berpengaruh terhadap hasil analisis. Adapun kriteria-kriteria yang dipilih dalam penentuan sampel adalah: (1) Perusahaan properti yang terdaftar di Bursa Efek Indonesia dari tahun 2004 - 2008; (2) Perusahaan menerbitkan laporan keuangan per 31 Desember tahun 2004 - 2008; (3) Perusahaan yang menyajikan laporan keuangan yang telah diaudit oleh auditor independen; (4) Perusahaan yang sahamnya aktif diperdagangkan di bursa.

Metode pengumpulan data yang digunakan dalam penelitian ini adalah strategi pengamatan langsung. Metode ini digunakan untuk mendapatkan data lapangan dan pengumpulan data dari basis data, dalam hal ini data-data yang terdapat pada laporan tahunan (annual report), yang sebagian besar diambil melalui download internet di www.idx.co.id dan juga dari bank data di Bursa Efek Indonesia (BEI).

Variabel adalah obyek penelitian atau apa yang menjadi titik perhatian suatu penelitian (Arikunto, 1996: 99). Dalam penelitian ini variabel yang menjadi pengamatan dan mempunyai indikator-indikator yang dapat dijabarkan sebagai berikut:

Variabel terikat (dependent variable), penelitian ini variabel dependennya adalah set peluang investasi atau investment opportunity set (IOS). 
Rasio dalam penelitian ini sebagai proksi IOS adalah market to book value of assets.

Variabel bebas (independent variable), Pertumbuhan ekuitas berkaitan dengan bagaimana terjadinya stabilitas peningkatan ekuitas kedepan.

Pengukuran Pertumbuhan Laba dapat diformulasikan sebagai berikut: (Warsidi dan Pramuka, 2000).

Total Laba tahun ke $\mathrm{t}$ - Total Laba tahun ke $\mathrm{t}-1$

Pertumb. Laba $=-100 \%$

Metode Analisis data merupakan suatu metode yang digunakan untuk memproses hasil penelitian guna memperoleh suatu kesimpulan dalam penelitian ini analisis yang digunakan adalah :

Statistik deskriptif digunakan untuk memperoleh gambaran umum sampel data. Hasil statistik deskriptif dari sampel data penelitian dapat dilihat melalui jumlah data, rata-rata sampel dan standar deviasi.

Uji asumsi klasik yang digunakan untuk mengetahui apakah model regresi linier berganda yang digunakan untuk menganalisis. Dalam penelitian ini memenuhi asumsi klasik atau tidak. Uji Asumsi klasik terhadap sampel data secara umum adalah :

Uji normalitas dimaksudkan untuk menentukan apakah variabel berdistribusi normal atau tidak, dapat dilihat dari nilai uji Kolmogorov dan Smirnov apabila variabel berdistribusi normal, maka nilai uji Kolmogorov dan Smirnov tersebut $>0,05$ (Danang Sunyoto, 2009:84)

Autokorelasi merupakan korelasi antara anggota dalam data runtut waktu (time series) atau antara ruang untuk data cross section. Jika terjadi autokorelasi maka persamaan tersebut menjadi tidak baik / tidak layak diprediksi.

Masalah autokorelasi baru timbul jika ada korelasi linier antara kesalahan pengganggu periode $t$ (berada) dan kesalahan pengganggu periode $t-1$ (sebelumnya).

(Danang Sunyoto, 2009:91-92) Pengujian terhadap adanya fenomena autokorelasi dalam data yang dianalisa dapat dilakukan dengan menggunakan Durbin-Wetson Test, dengan kriteria sebagai berikut : (1) Terjadi autokorelasi positif jika nilai DW dibawah $-2(\mathrm{DW}<-2)$; (2) Tidak terjadi autokorelasi jika nilai DW berada diantara -2 dan +2 atau $-2<$ DW $<+2$; (3) Terjadi autokorelasi negatif jika nilai $\mathrm{DW}$ diatas +2 atau $\mathrm{DW}>+$.

Dalam penelitian ini, uji Durbin Watson digunakan untuk mendeteksi keberadaan autokorelasi.

Jika variabel independen signifikan secara statistik mempengaruhi variabel dependen, maka ada indikasi terjadi heteroskedastisitas dengan probabilitas signifikansinya di bawah tingkat kepercayaan 5\% (Imam Ghozali, 2005). Masalah heteroskedastisitas sering dijumpai dalam data cross section dibanding time series (Sri Mulyono, 2005). 
Multikolinearitas merupakan fenomena adanya korelasi yang sempurna antara satu variabel bebas dengan variabel bebas yang lain.

Pengujian terhadap ada tidaknya multikolinearitas dapat dilakukan dengan cara : (Danang Sunyoto, 2009:79-80) : (1) Nilai tolerance adalah besarnya tingkat kesalahan yang dibenarkan secara statistik (a); (2) Nilai variance inflation factor (VIF) adalah faktor inflasi penyimpangan baku kuadrat; (3) Nilai tolerance (a) dan variance inflation factor (VIF) dapat dicari dengan menggabungkan kedua nilai tersebut sebagai berikut, yaitu Besar nilai tolerance (a): $\quad a=1 /$ VIF dan besar nilai variance inflation factor (VIF) : VIF $=1 /$ a.

Variabel bebas mengalami multikolinieritas jika a hitung $<$ a dan VIF hitung $>$ VIF. Variabel bebas tidak mengalami multikolinieritas jika a hitung $>$ a dan VIF hitung $<$ VIF

Dalam penelitian ini digunakan untuk mencari persamaan regresi atau pengaruh antara Pertumbuhan Ekuitas $\left(\mathrm{X}_{1}\right)$, Pertumbuhan Hutang $\left(\mathrm{X}_{2}\right)$, dan Pertumbuhan Laba $\left(\mathrm{X}_{3}\right.$ terhadap Investment Opportunity Set (IOS) (Y). Adapun rumus yang dipakai yaitu :

\section{Hasil dan Pembahasan}

Berikut adalah jumlah perusahaan yang masuk kategori Real Estate dan Property pada periode 2003 sampai dengan 2008.

Pada tahun 2003 terdapat 37 perusahaan yang masuk pada kategori real estate and property yang jumlahnya menjadi 38 pada tahun 2004 karena ada tambahan satu perusahaan yaitu PT Pembangunan Jaya Ancol Tbk. yang mulai listing pada tahun 2004. Pada tahun 2005 tidak ada perubahan jumlah pada kategori real estate and property sehingga jumlahnya tetap 38 perusahaan. Periode 2006 ada tambahan satu perusahaan yaitu PT Bukit Dharmo Property Tbk. Yang sebenarnya listing pada tahun 2007, tetapi sudah terdaftar sejak tahun 2006 sehingga total perusahaan ada sebanyak 39 perusahaan.

Pada tahun 2007 terjadi booming sehinga terdapat 10 perusahaan baru yang mulai menawarkan sahamnya di BEI, tetapi ada satu perusahaan yang keluar, sehingga total perusahaan adalah sebanyak 48 perusahaan dan yang berturut-turut adalah sebanyak 36 perusahaan. Lebih lanjut, pada tahun 2008 terdapat 1 perusahaan yang keluar dari bursa saham di BEI, sehingga perusahaan yang selama 2003 sampai dengan 2008 berturut-turut memperdagangkan sahamnya di BEI sebanyak 35 perusahaan.

Variabel dalam penelitian ini adalah Market Book Value of Asset (MBVA), pertumbuhan ekuitas, pertumbuhan hutang dan pertumbuhan laba. Variabel Market Book Value of Asset (MBVA) diukur berdasarkan nilai total assets, ekuitas, jumlah lembar saham dan harga penutupan saham. Dengan demikian, data mentah yang diperlukan dalam penelitian ini adalah data tentang total assets, ekuitas, jumlah lembar saham, harga penutupan saham, total hutang dan laba ber sih perusahaan yang selengkapnya ditampilkan pada Lampiran 2

Perhitungan masing-masing variabel menggunakan persamaan yang telah dipaparkan pada Bab II dan hasil perhitungan selengkapnya ditampilkan pada Lampiran 3, 4, dan 5. Berikut adalah statistik deskriptif dari masing-masing variabel dalam penelitian ini: 
Tampak bahwa nilai MBVA mempunyai rentang antara 0,11 sampai dengan 5,26 dengan rata-rata sebesar 1,0411 dan standar deviasi sebesar 0,6694. Semakin tinggi MBVA berarti semakin tinggi prospek pertumbuhan perusahaan karena mempunyai harga saham yang relatif tinggi. Nilai standar deviasi yang berada di bawah nilai rata-rata menunjukkan bahwa data relatif tidak berfluktuasi, yang berarti kesempatan bertumbuh perusahaan sampel tidak terlalu banyak bervariasi antara satu perusahaan dengan perusahaan yang lain.

Variabel pertumbuhan ekuitas mempunyai rentang antara $-8599,62$ sampai dengan 60559,23 dengan rata-rata sebesar 369,6439 dan standar deviasi sebesar 4635,8134. Tampak bahwa pertumbuhan ekuitas perusahaan sampel sangat bervariasi yang juga ditunjukkan dengan nilai standar deviasi yang jauh di atas nilai rata-ratanya. Tampak bahwa ada perusahaan yang mengalami penurunan ekuitas sampai dengan 85,99 kali dibandingkan satu tahun sebelumnya, tetapi ada juga perusahaan yang mengalami peningkatan ekuitas sampai dengan 605,59 kali dibandingkan periode tahun sebelumnya.

Adanya fluktuasi juga dijumpai pada variabel pertumbuhan laba, di mana mempunyai rentang antara $-4069,84$ sampai dengan 7176,56 dengan rata-rata sebesar 56,1161 dan standar deviasi sebesar 874,65877. Tampak bahwa ada perusahaan yang mengalami penurunan laba sampai dengan 40,69 kali dibandingkan periode sebelumnya, tetapi ada juga perusahaan yang mengalami peningkatan 71,76 kali dibandingkan periode tahun sebelumnya.

Seperti tampak pada statistik deskriptif di atas, bahwa banyak data yang berfluktuatif, maka perlu dilakukan trimming data yang masuk kategori outlier.

Menurut Ghozali (2006:36), Outlier adalah kasus atau data yang memiliki karakteristik unik yang terlihat sangat berbeda jauh dari observasi-observasi lainnya dan muncul dalam bentuk nilai ekstrim baik untuk sebuah variabel tunggal atau variabel kombinasi.

Ketiga data pada Tabel 4.4 di atas dikeluarkan dari model penelitian sehingga tidak terdapat data outlier lagi dan pengujian asumsi klasik dapat dilakukan.

Pada uji normalitas dengan Kolmogorov Smirnov, residual yang normal ditunjukkan dengan signifikansi di atas 0,5 yaitu sebagai berikut: Tampak bahwa nilai signifikansi adalah sebesar $0,509(>0,05)$ yang menunjukkan bahwa residual mempunyai distribusi yang normal. Dengan demikian asumsi normalitas pada model telah terpenuhi.

Hasil uji normalitas terlihat bahwa sebaran data pada grafik bisa dikatakan tersebar disekeliling garis diagonal atau tidak terpencar jauh dari garis diagonal. Dengan demikian dapat disimpulkan bahwa persyaratan normalitas bisa dipenuhi. Tampak bahwa nilai DW adalah sebesar 1,600 yang terletak antara -2 sampai dengan 2 yang diinterpretasikan bahwa tidak terjadi gangguan autokorelasi pada model penelitian. Hasil ini menunjukkan bahwa model telah terbebas dari gangguan multikolinearitas dan memenuhi asumsi klasik untuk mendapatkan Best Linear Unbiased Estimate (BLUE).

Hasil uji heteroskedastisitas dapat dibaca dari Scatterplot seperti tampak pada gambar di bawah: 
Tampak bahwa terjadi penyimpangan heteroskedastisitas yang ditunjukkan dengan adanya titik pada grafik yang menyimpang terlalu jauh dari data yang lain. Dengan mengeluarkan titik-titik yang menyimpang sehingga diperoleh uji Glejser sebagai berikut: Tabel 4.7 di atas menunjukkan bahwa tidak ada variabel bebas yang mempunyai pengaruh signifikan terhadap nilai absolut residual yang menunjukkan bahwa tidak terdapat gangguan heteroskedastisitas pada model penelitian. Dengan demikian, pengujian dapat dilanjutkan.

Pada Uji Multikolinearitas Nilai VIF dari variabel-variabel bebas tidak ada yang melebihi 10. Nilai VIF yang tertinggi adalah Pertumbuhan Hutang yaitu sebesar 1,073 yang menunjukkan bahwa tidak terdapat gangguan multikolinearitas pada model penelitian.

Koefisien korelasi (R) dan Determinasi (Adjusted $R$ Square) yang didapat dari uji regresi linier berganda sebagaimana terlihat pada Tabel 4.9

Tabel 4.9

Korelasi dan Determinasi

Model Summary(b)

\begin{tabular}{lcrrrr}
\hline Model & R & R Square & $\begin{array}{c}\text { Adjusted } \\
\text { R Square }\end{array}$ & $\begin{array}{c}\text { Std. Error of the } \\
\text { Estimate }\end{array}$ & Durbin-Watson \\
\hline 1 & $.824(\mathrm{a})$ & .614 & .604 & .74586 & 1.600 \\
\hline
\end{tabular}

a. Predictors: (Constant), Pertumbuhan Laba, Pertumbuhan Ekuitas, Pertumbuhan Hutang

b. Dependent Variable: MBVA

Tampak bahwa nilai $\mathrm{R}$ adalah sebesar 0,824 dan nilai koefisien determinasi adalah 0,604 . Berarti $60,4 \%$ variasi perubahan dari variabel dependen (Investment Opportunity Set) dapat dijelaskan oleh variasi perubahan variabelvariabel independen (pertumbuhan ekuitas, pertumbuhan hutang dan pertumbuhan laba) dalam model. Sedangkan sisanya sebesar 39,6\% dipengaruhi oleh variabel lain yang berada diluar persamaan (model) atau yang tidak diteliti.

Secara umum, pengaruh pertumbuhan ekuitas, pertumbuhan hutang, dan pertumbuhan laba terhadap Investment Opportunity Set (IOS) adalah sebesar $60,8 \%$.

Model regresi yang terbentuk adalah sebagai berikut :

$$
\begin{gathered}
Y=-0,302+0,416 X 1+0,312 X 2 \\
\text { Atau } \\
I O S=-0,302+0,416 P E+0,312 P L
\end{gathered}
$$

Uji $\mathrm{t}$ digunakan untuk mengetahui apakah masing-masing variabel independen mempunyai pengaruh secara signifikan terhadap variabel dependennya.

Uji t terhadap $\alpha 1$

Ho : $\alpha 1=0$, Pertumbuhan ekuitas tidak berpengaruh secara parsial terhadap Investment Opportunity Set 
Ha: $\alpha 1 \neq 0, \quad$ Pertumbuhan ekuitas secara signifikan berpengaruh secara parsial terhadap Investment Opportunity Set

Tampak bahwa nilai signifikansi untuk pertumbuhan ekuitas adalah sebesar 0,017 yang nilainya di bawah 0,05 . Karena nilai signifikansi di bawah 0,05 maka Ho ditolak dan Ha diterima, berarti terdapat pengaruh yang signifikan variabel pertumbuhan ekuitas terhadap Investment Opportunity Set (IOS).

\section{Uji t terhadap $\alpha 2$}

Ho: $\alpha 2=0$, Pertumbuhan laba tidak berpengaruh secara parsial terhadap

Investment Opportunity Set

Karena signifikansi adalah sebesar 0,032 <0,05 maka Ho ditolak dan $\mathrm{Ha}$ diterima, berarti terdapat pengaruh yang signifikan variabel pertumbuhan laba terhadap Investment Opportunity Set (IOS).

Uji F digunakan untuk mengetahui apakah ada pengaruh/hubungan antara variabel independen secara bersama-sama terhadap variabel dependennya.

Hipotesis :

Ho : $\alpha 1=\alpha 2=\alpha 3=\alpha 4$, Pertumbuhan ekuitas dan pertumbuhan laba tidak berpengaruh secara simultan terhadap Investment Opportunity Set.

Ha: $\alpha 1 \neq \alpha 2 \neq \alpha 3 \neq \alpha 4$, Pertumbuhan ekuitas dan pertumbuhan laba secara signifikan berpengaruh secara simultan terhadap Investment Opportunity Set

Tampak bahwa signifikansi hasil perhitungan adalah sebesar $0,001<0,05$ yang menunjukkan bahwa secara simultan variabel bebas dalam penelitian ini berpengaruh terhadap Investment Opportunity Set (IOS). Dengan demikian hipotesis 4 dalam penelitian ini menyatakan bahwa 'Pertumbuhan ekuitas, pertumbuhan laba secara signifikan berpengaruh secara simultan terhadap Investment Opportunity Set' diterima.

Hasil analisis menunjukkan bahwa dari ketiga variabel bebas yang dipergunakan dalam penelitian ini menunjukkan bahwa variabel pertumbuhan ekuitas dan pertumbuhan laba mempunyai pengaruh signifikan terhadap Investment Opportunity Set (IOS) baik secara parsial maupun secara simultan.

Variabel pertumbuhan ekuitas dalam penelitian ini mempunyai pengaruh signifikan terhadap Investment Opportunity Set (IOS). Berdasarkan nilai koefisien dan $\mathrm{t}$ hitung yang positif maka tampak bahwa pertumbuhan ekuitas berpengaruh positif terhadap Investment Opportunity Set (IOS), artinya semakin tinggi pertumbuhan ekuitas, maka Investment Opportunity Set (IOS) juga akan meningkat. Komponen modal sendiri ini merupakan modal perusahaan yang dipertaruhkan untuk segala risiko, baik risiko usaha maupun risiko-risiko kerugian lainnya. Modal sendiri ini tidak memerlukan jaminan atau keharusan untuk pembayaran kembali dalam setiap keadaan maupun tidak adanya kepastian tentang jangka waktu pembayaran kembali modal sendiri. Oleh karena itu, tiaptiap perusahaan harus mempunyai jumlah minimum modal yang diperlukan untuk menjamin kelangsungan hidup perusahaan. 
Modal sendiri yang bersifat permanen akan tetap tertanam dalam perusahaan dan dapat diperhitungkan pada setiap saat untuk memelihara kelangsungan hidup dan melindungi perusahan dari risiko kebangkrutan. Modal sendiri merupakan sumber dana perusahaan yang paling tepat untuk diinvestasikan pada aktiva tetap yang bersifat permanen dan investasi-investasi yang menghadapi risiko kerugian yang relatif kecil, karena suatu kerugian atau kegagalan dari investasi tersebut dengan alasan apapun merupakan tindakan membahayakan bagi kontinuitas kelangsungan hidup perusahaan. Apabila kebutuhan dana sudah semakin meningkat karena pertumbuhan perusahaan, dan dana dari sumber intern sudah digunakan semua, maka tidak ada pilihan lain menggunakan dana lain yang bersumber dari luar perusahaan baik berupa hutang maupun dengan mengeluarkan saham baru.

Demikian juga dengan pertumbuhan laba, semakin tinggi pertumbuhan laba maka akan semakin tinggi peluang perusahaan untuk melakukan ekspansi atau diversifikasi usaha sehingga membuka peluang adanya potensi pertumbuhan perusahaan. Hal ini didukung dengan hasil analisis yang menunjukkan bahwa petumbuhan laba mempunyai pengaruh positif terhadap Investment Opportunity Set (IOS) karena nilai t hitung dan koefisien regresi adalah positif.

Besar kecilnya laba sebagai pengukur kenaikan sangat bergantung pada ketepatan pengukuran pendapatan dan biaya. Jadi dalam hal ini laba hanya merupakan angka artikulasi dan tidak didefinisikan tersendiri secara ekonomik seperti halnya aktiva atau hutang (Chariri dan Gozali, 2003:213).

Menurut Harahap (2005:263) laba merupakan angka yang penting dalam laporan keuangan karena berbagai alasan antara lain: laba merupakan dasar dalam perhitungan pajak, pedoman dalam menentukan kebijakan investasi dan pengambilan keputusan, dasar dalam peramalan laba maupun kejadian ekonomi perusahaan lainnya di masa yang akan datang, dasar dalam perhitungan dan penilaian efisiensi dalam menjalankan perusahaan, serta sebagai dasar dalam penilaian prestasi atau kinerja perusahaan.

Myers (1977) yang dikutip dari (Gumanti dan Puspitasari, 2008) menyatakan bahwa nilai perusahaan sebagai kombinasi antara aset yang dimiliki dan peluang investasi. Laba yang tinggi memberikan sinyal mengenai pertumbuhan perusahaan di masa yang akan datang. Disebutkan juga oleh AlNajjar dan Belkauoi (1999) yang dikutip dari (Gumanti dan Puspitasari, 2008) bahwa sebagian dari laba tersebut akan ditanamkan lagi dalam bentuk investasi untuk meningkatkan perusahaan.

\section{Simpulan dan Saran Simpulan}

Berikut adalah beberapa kesimpulan yang dapat ditarik berd asarkan analisis terhadap data penelitian:

1. Terdapat pengaruh yang signifikan antara pertumbuhan ekuitas terhadap Investment Opportunity Set (IOS). Dengan demikian hipotesis $\mathrm{H} 1$ dalam penelitian ini yang menyatakan bahwa 'Pertumbuhan ekuitas secara signifikan berpengaruh secara parsial terhadap Investment Opportunity Set' diterima. 
2. Terdapat pengaruh yang signifikan antara pertumbuhan laba terhadap Investment Opportunity Set (IOS). Dengan demikian hipotesis $\mathrm{H} 2$ dalam penelitian ini yang menyatakan bahwa 'Pertumbuhan laba secara signifikan berpengaruh secara parsial terhadap Investment Opportunity Set' diterima.

3. Terdapat pengaruh yang signifikan antara pertumbuhan ekuitas dan laba terhadap Investment Opportunity Set (IOS). Dengan demikian hipotesis H3 dalam penelitian ini yang menyatakan bahwa 'Pertumbuhan ekuitas dan pertumbuhan laba berpengaruh secara simultan terhadap Investment Opportunity Set' diterima.

\section{Saran}

1. Penelitian mendatang disarankan untuk menggunakan proxy laba terhadap Investment Opportunity Set (IOS) dengan metode lain selain Market Book Value of Asset (MBVA) untuk mendapatkan hasil yang lebih komprehensif.

2. Disarankan untuk memisahkan model penelitian berdasarkan siklus hidup perusahaan sehingga akan diperoleh hasil yang lebih sesuai dengan kondisi perusahaan yang sebenarnya.

3. Bagi para investor yang akan melakukan transaksi saham di Bursa Efek Jakarta khususnya pada perusahaan properti dan real estate hendaknya lebih memperhatikan kondisi pertumbuhan suatu perusahaan.

4. Investor perlu mempertimbangkan sinyal pertumbuhan perusahaan sebelum melakukan transaksi saham dan dalam melakukan investasi pada saham.

5. Bagi pihak manajemen dapat mempertimbangkan Investment Opportunity Set (IOS) dalam pengambilan keputusan investasi yang akan dilakukan pada masa yang akan datang.

6. Secara umum disarankan agar hasil penelitian lebih akurat, sebaiknya ketersediaan data, kendala waktu, dan hal-hal lain yang dapat mempengaruhi penelitian tersebut dapat dipersiapkan dengan baik dan matang.

\section{Daftar Pustaka}

Adler Haymans Manurung, dkk. 2009. Economic Outlook 2009 : Perjuangan Melawan Krisis. PT. Finansial Bisnis Indonesia.

Agus Sartono. 2008. Manajemen Keuangan : Teori dan Aplikasi. Edisi Empat, BPFE: Yogyakarta.

Agustina M.V. Norpratiwi, 2001. Analisis Korelasi Investment Opportunity Set Terhadap Return Saham (Pada Saat Pelaporan Keuangan Perusahaan), STIE YKPN Yogyakarta, 1-28

Ardi Hamzah, 2006. Analisis Rasio Likuiditas, Profitabilitas, Aktivitas, Solvabilitas dan Investment Opportunity Set Dalam Tahapan Siklus Kehidupan Perusahaan Manufaktur Yang Terdaftar Di Bursa Efek Jakarta (BEJ) Tahun 2001-2005, Universitas Trunojoyo Madura, 1-22

Bambang Agus Pramuka. 2002. Evaluasi Kegunaan Rasio Keuangan Dalam Memprediksi Perubahan Laba di Masa Yang Akan Datang: Studi Empiris Pada Perusahaan Yang Terdaftar di BEJ, Tesis, Universitas Gadjah Mada. Tidak dipublikasikan, 
Bambang Riyanto. 1995. Dasar-Dasar Pembelanjaan Perusahaan, Edisi Keempat. Yogyakarta: BPFE UGM.

Beaver, Williams. 1966. Jurnal Of Accounting Research "Financial Ratios as Predictor of Failare, Empirical Research in Accounting: Selected Studies Suplement", Vol.5.

Belkaoui, Ahmed Riahi. 2003, Anticipatory Income Smoothing and The Investment Opportunity Set: An Empirical Test of the Fudenberg and Tirole (1995) Model, Review of Accounting \& Finance, 2(2): 99-117

Bramantyo Djohanputro, Phd. 2008. Manajemen Keuangan Korporat, PPM: Jakarta.

Brigham \& Houston. 2006Dasar-dasar Manajemen Keuangan. Edisi Kesepuluh, Jakarta: Salemba Empat.

Cooper, Donal R. and Emory, C. William. 2000. Metode Penelitian Bisnis. Alih Bahasa: Ellen G. Sitompul dan Imam Nurmawan. Jakarta: Erlangga.

C. Trihendradi. 2008. Step by Step SPSS 15 Analisis Data Statistik. Yogyakarta: Andi.

Danang Sunyoto. 2009. Analisis Regresi dan Uji Hipotcsis. Yogyakarta: MedPress.

Dian Waskito, 2008. Analisis Faktor-Faktor Yang Mempengaruni Pertumbuhan Modal Sendiri Perusahaan Manufaktur Yang Terdaftar Di Bursa Efek Jakarta, Tesis, Sekolah Pascasarjana Universitas Sumatera Utara Medan

Gaver, Jennifer J, Gaver, Kenneth M. 1995. Compensation Policy and The Investment Opportunity Set, Financial Management, 24(1) : 14-19

Gujarati, D, Basic Econometrics, Third Edition, Mc-Graw Hil, Inc.: New York, 1995

Ghozali, Imam, 2006. Aplikasi Analisis Multivariate dengan Program SPSS, Badan Penerbit Universitas Diponegoro, Semarang.

Handono Mardiyanto, Intisari Manajemen Keuangan, Grasindo: Jakarta, 2009

Isnaeni Rokhayati. 2005, Analisis Hubungan Investment Opportunity Set (IOS) dengan realisasi Pertumbuhan serta Perbedaan Perusahaan yang Tumbuh dan Tidak Tumbuh Terhadap Kebijakan Pendanaan dan Dividen di Bursa Efek Jakarta, SMART, 1 ( 2) : 41-60

Imam Subekti dan MAF Suprapti. 2002, Asosiasi Antara Potensi Pertumbuhan Perusahaan Dengan Volume Perdagangan Saham Dan Asimetri Informasi, Simposium Nasional Akuntansi, 5: 356-370

Ikatan Akuntansi Indonesia. 2007. Standar Akuntansi Keuangan. Jakarta: Salemba Empat.

Kumalahadi. 2003, Pengaruh Pertumbuhan dan Utang Terhadap Asosiasi Nilai Pasar - Laba dan Nilai Buku Ekuitas, JAAI, 7(1), Juni 2003

Korkie, Bob. and Turtle, Harry. 1998, The Canadian Investment Opportunity Set, 1967 - 1993, Canadian Journal of Administrative Sciences, 15(3) : 213-229

Lampiran 11. Surat Edaran Ketua Badan Pengawas Pasar Modal, Nomor : SE02 /PM/2002 Tanggal : 27 Desember 2002

Levin, Richard I, David S. Rubin. 1991. Statistics for Management. Fifth Edition. Prentice Hall. 
Marisi. P. Purba. 2008. Aspek Akuntansi Undang-undang Perseroan Terbatas : Suatu Pembahasan Kritis Atas Undang-Undang No 40 Tahun 2007 Tentang Perseroan Terbatas, Edisi Pertama, Graha Ilmu: Yogyakarta,

RM. Riadi Ngadlan. 2004. Pengaruh Investment Opportunity Set (IOS) Dengan Tingkat Pertumbuhan (Sustainable Growth) di Bursa Efek Jakarta, 2004

Sekaran, Uma. 2006. Metodologi Penelitian untuk Bisnis. Alih Bahasa : Kwan Men Yon. Buku Dua. Edisi Empat, Jakarta: Salemba Empat.

Sjahrial Dermawan. 2008. Manajemen Keuangan Lanjutan. Jakarta: Mitra Wacana Media.

Sri Mulyono. 2005. Statistika Untuk Ekonomi dan Bisnis, Edisi Ketiga. Jakarta: LPDE UI.

Sujoko Efferin, Stevanus Hadi Darmadji, dan Yuliawati Tan. 2008. Metode Penelitian Akuntansi: Mengungkap Fenomena dengan Pendekatan Kuantitatif dan Kualitatif. Yogyakarta: Graha Ilmu.

Suratno. 2005. Pengaruh Set Peluang Investasi, Asimetri Informasi, Manajemen Aset, Pengungkit, dan Kepemilikan Manajerial Terhadap Pertumbuhan Terealisasi Serta Implikasinya Pada Nilai-Nilai Perusahaan, Disertasi Program Doktor Ilmu Ekonomi Bidang Akuntansi, Universitas Persada Indonesia YAI, Tidak dipublikasikan.

Suwardjono. 2006. Teori Akuntansi : Perekayasaan Pelaporan Keuangan. Yogyakarta: BPFE.

Tatang Ary Gumanti dan Novi Puspitasari, 2008. Siklus Kehidupan Perusahaan Dan Kaitannya Dengan Investment Opportunity Set, Risiko, Dan Kinerja Finansial, Jurnal Akuntansi \& Bisnis, 8(2): 139-150

Weston, J. Fred, Eugene F.Brigham, 1990, Manajemen Keuangan, Edisi Sembilan. Jakarta: Erlangga.

Wild, Subramanyam, Halsey. 2007. Financial Statement Analysis. Nine Edition, McGraw Hill.

Yetty Iswahyuni dan L. Suryanto, 2002. Analisis Perbedaan Perusahaan Tumbuh dan Tidak Tumbuh Dengan Kebijakan Pendanaan, Deviden, Perubahan Harga Saham dan Volume Perdagangan Pada Bursa Efek Jakarta dengan Pendekatan Asosiasi Proksi Investment Opportunity Set (IOS), Jurnal Bisnis dan Ekonomi, September. 2002 